有機溶媒加染色しをとをの分散染料の親和力， 溶解熱叔よび染色熱†

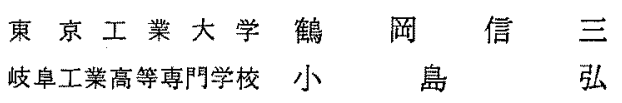

\title{
ON THE AFFINITY, HEAT OF SOLUTION AND HEAT OF DYEING OF DISPERSE DYES FROM ORGANIC SOLVENTS
}

\author{
By Shinzō Tsuruoka* and Hiroshi Kojima** \\ *(Tokyo Institute of Technology, Ookayama, Meguro-ku, Tokyo, Japan) \\ **(Gifu Technical College, Motosu-gun, Gifu Prefecture, Japan)
}

\begin{abstract}
In order to know dyeing properties and the mechanism of disperse dyes in three different solvents, measurements of the solubilities of disperse dyes in octane, $n$-buthylalcohol, and water and pertition coefficients from these solutions, have been made at the temperatures of $80^{\circ}$, $90^{\circ}$ and $100^{\circ} \mathrm{C}$. Affinities, heat of dyeing and heat of solution have been derived. From these values, the absolute heat of association of the dyes with the PET-substrate $\left(\Delta H_{a b s}\right)$ has been estimated, and the following results have been obtained.

1. The greater the values of solubility, the smaller the values of affinity irrescective of solvents.

2. The higher the values of inorganicity/organicity of dyes, the greater the solubilities of dyes in water, but the smaller in the case of octane.

3. It is suggested from the values of $\Delta H_{\mathrm{abs}}(23 \sim 35 \mathrm{Kcal} / \mathrm{mol})$ that dispersion force between aromatic nucleus of PET molecule and aromatic or anthraquinone nucleus of dye molecule makes a considerable part of contribution to the dye-PET interaction, and additionally, dipole-dipole interaction or hydrogen bond makes a contribution to interaction.

(Received May 13, 1967)
\end{abstract}

\section{1. 緒言}

分散染料の染着機構を解明する目的で有機溶媒染色法 研究した。これに関する研究は, Whiteり らの研究が あるが，熱力学的関数值についての研究は湏田 ${ }^{2)}$ のの しか見当らない。須田2)の研究では，エタノール溶液か ら染色したときの染着状態と結晶状態のェンタルピー恋 化について検討を行なつている。しかし，染浴の溶媒を 变えたときの相互間における熱力学的関数値について は，触れていない。そこで，著者は哭極性溶煤であるオ クタン、極性溶媒でする $n$ るプチルアルコール拈よび水 溶液を用いて，ポリエチレンテレフタレート(PET) 物 質を染色し，この場合の分散染料の親和力，エンタルビ 一の值を比較检詰し，染浴の溶媒が变わつたとさに分散 染料の染色性と染着機構がどのように変化するか議論 した。

†本啹を分散染料の染色性に関する研究（第 7 報）々

\section{2. 試料および実験方法}

\section{$2 \cdot 1$ 供試分散染料と被染物}

これらのものは，すへて前報ると同じすを使用し た。供試染料構造は表 2 に示した。

\section{$2 \cdot 2$ 分散染料の飽和溶解度の測定}

染料の遄剩量を加えた溶液を所定温度に保ち，同温度 のG 4 グラスフィルター付ピペットで所定量を重量法で

とり，その濃度を前報引 と同様に分光学的に測定した。

この場合，重量を体䞍に換算するには各溶液の密度が 必要でるる。したがって，水溶液については化学便覧》 の水の密度を引用し，nープチルアルニール和よびオクタ ンについては、この值を測定して決めた。これらの值を 表エに示した。なお，濃度が䬶和になるむでの時間は， 多くの場合，3日間以上が必要であつた。

\section{$2 \cdot 3$ 平衡染色実験}

前報引に準じて行なつたが，染色時間は予借実験の結 果, 表 1 のように決めた。 
Table 1. Density of solvents and dyeing condition

\begin{tabular}{|c|c|c|c|c|c|c|}
\hline \multirow[b]{2}{*}{$\underset{{ }^{\circ} \mathrm{C}}{\text { Temp. }}$} & \multicolumn{2}{|c|}{ water } & \multicolumn{2}{|c|}{ octan } & \multicolumn{2}{|c|}{$n$-buthyl alcohol } \\
\hline & $\begin{array}{l}\text { Density } \\
\mathrm{g} / \mathrm{cm}^{\mathrm{s}}\end{array}$ & $\underset{\text { hr }}{\text { Time }}$ & $\begin{array}{c}\text { Density } \\
\mathrm{g} / \mathrm{cm}^{3}\end{array}$ & $\underset{\mathrm{hr}}{\operatorname{Time}}$ & $\begin{array}{c}\text { Densiey } \\
\mathrm{g} / \mathrm{cm}^{3}\end{array}$ & $\underset{\mathrm{hr}}{\mathrm{Time}}$ \\
\hline 80 & 0.972 & 240 & 0.693 & 360 & 0.760 & 24 \\
\hline 90 & 0.965 & 48 & 0.686 & 72 & 0.752 & 4 \\
\hline 100 & 0.958 & 6 & 0.680 & 24 & 0.744 & 1 \\
\hline
\end{tabular}

が，モノアゾ染料は，一定の濃度以 上では，翼状に高い吸着が行なわ れ，分配型の吸着曲線から外れるこ とを見い出し，この原因について考 察している。しかし，この実験に用 いたオクタン拈よび nーブチルアル コール溶液では，アジ、ジフェニル およびアントラキノン系のいずれの

\section{3. 実験結果および考察}

\section{$3 \cdot 1$ 等温吸着曲線}

オクタン和よび $n$ ーブチルアルコール溶液から PET 物 質を染色した場合の，100 $\mathrm{C}$ K括ける等温吸着曲線を求 めた。これらの結果を図 1に示した。

精製分散染料を用いて，水溶液加ら合成瀻維を染色 した場合，その等温吸着曲線が分配型の吸着を示すこと はよく知られているすう。た，有機溶媒からアセテート䋐 䧽を染色した場合については，White' ${ }^{1)}$ らの Langmuir 型の吸着説と須田 ${ }^{2}$ の分配型の眨着説とがある。この奏 験結果によれば，須田2)が打説しているよ5に，分配型 の吸着曲線を示した。しかし，須田 ${ }^{2}$ はエタノール溶液 からアセテート㵶維を染色した場合，アントラキノン系 分散染料は，飽和惯度まで分配型の吸着曲線にしたがう
染料に拁いても，このような異状な吸着は認められず， 分配型の吸着曲湶を示した。

\section{2 分配保数亡飽和溶解度}

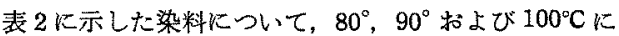

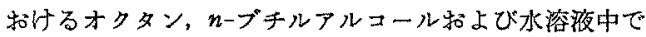
の染料の飽和溶解度を求めた。京たこれらの溶媒から 染色したときの分配保数をも求めた。これらの結果を茷 2 に示した。

\section{3 染料の標染親和力と溶解度との関係}

染料の標染親和力の值は(1)式で示される。

$$
-\Delta \mu^{\circ}=R T \ln \left[D_{f}\right] /\left[D_{s}\right]
$$

$\left[D_{f}\right]$; 染着有効体積を用いたとさの物質中の染料灌 度 $(\mathrm{mol} / \mathrm{l})$

$\left[D_{s}\right]$; 染浴濃度 $(\mathrm{mol} / l)$

金丸 ${ }^{6)}$ は，100\% RH 中での昅水量が，染着有効体皘

Table 2. Partition coefficient and solubility of dyes in each of the solvents

\begin{tabular}{|c|c|c|c|c|c|c|c|c|c|}
\hline $\begin{array}{l}\text { Dye } \\
\text { No. }\end{array}$ & Formula & $\mathrm{X}$ & $\underset{{ }^{\circ} \mathrm{C}}{\text { Temp. }}$ & \multicolumn{3}{|c|}{$\begin{array}{l}\text { Solubility of Dyes } \\
\left(\times 10^{3} \mathrm{~mol} / l\right)\end{array}$} & \multicolumn{3}{|c|}{$\begin{array}{c}\text { Partition Coefficient } \\
\text { octane } \begin{array}{l}n \text {-buthyl water } \\
\text { alcohol }\end{array}\end{array}$} \\
\hline 1 & & $\mathrm{NH}_{2}$ & $\begin{array}{r}100 \\
90 \\
80\end{array}$ & $\begin{array}{l}1.44 \\
1.00 \\
0.650\end{array}$ & & $\begin{array}{l}0.366 \\
0.195 \\
0.0885\end{array}$ & $\begin{array}{l}55.6 \\
67.4 \\
94.4\end{array}$ & & $\begin{array}{l}233 \\
319 \\
551\end{array}$ \\
\hline 2 & & $\mathrm{OH}$ & $\begin{array}{r}100 \\
90 \\
80\end{array}$ & $\begin{array}{l}6.80 \\
4.56 \\
3.14\end{array}$ & $\begin{array}{l}72.9 \\
54.2 \\
37.9\end{array}$ & $\begin{array}{l}0.175 \\
0.0779 \\
0.0471\end{array}$ & $\begin{array}{l}13.1 \\
18.9 \\
24.6\end{array}$ & $\begin{array}{l}1.29 \\
1.44 \\
1.64\end{array}$ & $\begin{array}{r}758 \\
1150 \\
1870\end{array}$ \\
\hline 3 & $\mathrm{X}$ & $\mathbf{H}$ & $\begin{array}{r}100 \\
90 \\
80\end{array}$ & $\begin{array}{l}6.10 \\
4.22 \\
2.87\end{array}$ & & $\begin{array}{l}0.139 \\
0.0795 \\
0.0430\end{array}$ & $\begin{array}{l}10.3 \\
12.4 \\
15.7\end{array}$ & & $\begin{array}{r}457 \\
638 \\
1030\end{array}$ \\
\hline 4 & & $\mathrm{NH}_{2}$ & $\begin{array}{r}100 \\
90 \\
80\end{array}$ & $\begin{array}{l}1.45 \\
0.835 \\
0.501\end{array}$ & & $\begin{array}{l}0.215 \\
0.130 \\
0.0969\end{array}$ & $\begin{array}{c}83.7 \\
97.1 \\
108\end{array}$ & & $\begin{array}{l}324 \\
375 \\
450\end{array}$ \\
\hline 5 & & OH & $\begin{array}{r}100 \\
90 \\
80\end{array}$ & $\begin{array}{l}0.642 \\
0.373 \\
0.226\end{array}$ & & $\begin{array}{l}1.29 \\
0.706 \\
0.384\end{array}$ & $\begin{array}{l}187 \\
295 \\
446\end{array}$ & & $\begin{array}{l}215 \\
303 \\
473\end{array}$ \\
\hline 6 & & $\mathbf{H}$ & $\begin{array}{r}100 \\
90 \\
80\end{array}$ & $\begin{array}{l}27.8 \\
20.4 \\
12.3\end{array}$ & & $\begin{array}{l}0.125 \\
0.0964 \\
0.0603\end{array}$ & $\begin{array}{c}7.39 \\
8.75 \\
10.7\end{array}$ & & $\begin{array}{r}986 \\
1390 \\
2070\end{array}$ \\
\hline 7 & & $\mathrm{NH}_{2}$ & $\begin{array}{r}100 \\
90 \\
80\end{array}$ & $\begin{array}{l}3.03 \\
1.98 \\
1.23\end{array}$ & $\begin{array}{l}81.4 \\
57.6 \\
39.3\end{array}$ & $\begin{array}{l}0.126 \\
0.0635 \\
0.0400\end{array}$ & $\begin{array}{l}25.3 \\
30.7 \\
43.7\end{array}$ & $\begin{array}{l}0.933 \\
1.12 \\
1.30\end{array}$ & $\begin{array}{r}652 \\
1050 \\
1540\end{array}$ \\
\hline 8 & & $\mathrm{OH}$ & $\begin{array}{r}100 \\
90 \\
80\end{array}$ & $\begin{array}{l}4.06 \\
2.59 \\
1.64\end{array}$ & & $\begin{array}{l}0.822 \\
0.536 \\
0.340\end{array}$ & $\begin{array}{l}35.2 \\
49.5 \\
66.6\end{array}$ & & $\begin{array}{l}325 \\
513 \\
803\end{array}$ \\
\hline
\end{tabular}




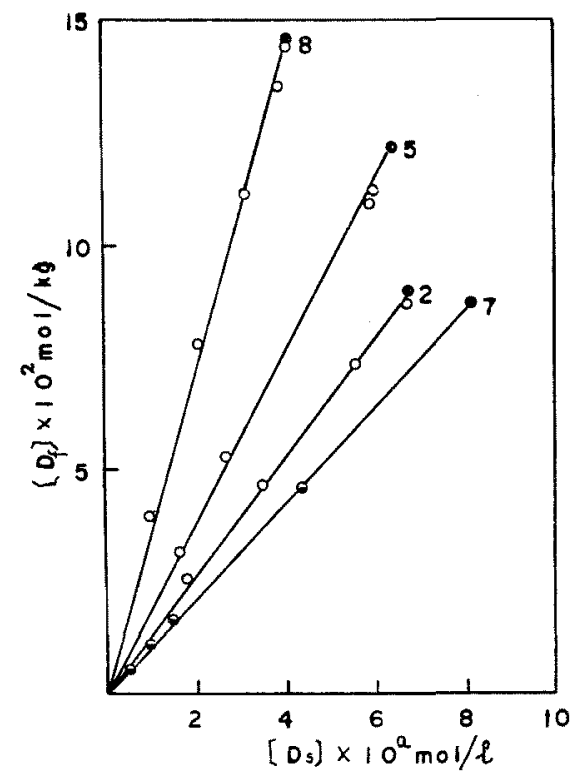

Fig. 1. Equilibrium isotherms of disperse dyes from octane or $n$-buthyl alcohol solution at $100^{\circ} \mathrm{C}$

The numbers on the figure are the dye number of Table 1.

$\bigcirc:$ octane $\ominus: n$-buthyl alcohol $\bigcirc$ :saturation value

$a=2:$ dye No. $7, a=3:$ dye No. 2 and, 8 $a=4:$ dye No. 5 .

とよく一致することを述べている。100\% RH 中での $\mathrm{PE}$ T 物質の吸水量は $0.005 l / \mathrm{kg}^{6}$ ) である。1:4-ジアミノ アントラキノンの $100^{\circ} \mathrm{C}$ における飽和染着量は PET 物

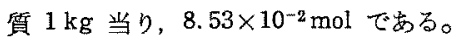

この染料の分子容は約 $170 \mathrm{~cm}^{3 *}$ になるので, PET 物 質 $1 \mathrm{~kg}$ の中で占める染料の体積は，0.0145l となり， $100 \% \mathrm{RH}$ 中での吸水量から求めた欢かけ染着有效体 積よりも大きくなる。したがつて，PET 物質の場合， $100 \% \mathrm{RH}$ 中での吸水量から染着有效体積を決めること は疑閣がおる。

この他に，この値を適確に俨価する実験も現在のとこ ろ確立されていない。いまのところ，この值はすべての 研究に扣いて, 染料の種類に関保なく, 同一として取り

*フミノフントラキノンの比重は 1.4 である。1:4ジミノフントラキノンの比重も，フントラキノンの 值と大きく变わらないことが予想される。したがっ て, 1:4ーシフミノアントラキノンの $1 \mathrm{~g}$ 分子を比重 1.4 で割った值を分子容とした。な拈，ナフタリンの 分子容は $111.84 \mathrm{~cm}^{3}$ (小竹無雄監修大有機化学, 別巻 2 有機化学定数便覽より引用)である。

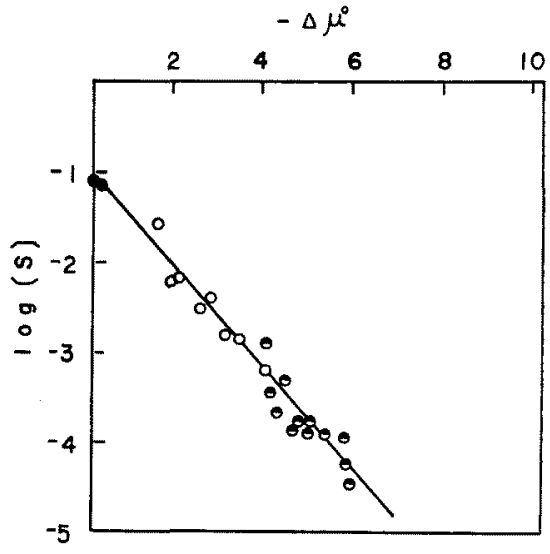

Fig. 2. Relationship between affinity and solubility of dyes at $100^{\circ} \mathrm{C}$.

$\bigcirc$ : octane, $\theta$ : water, $\theta$ : $n$-buthylalcohol.

扱われているが，染浴に異なる溶媒を用いたときこの 倠を同一として取り报うことには，多くの疑閣がある。

しかし，この実験に用いた溶媒は須田 ${ }^{2)}$ が見い出した ような，縟度以上においては，分配型の吸着から外 れるごとき，異状に亮い吸着は見当らず，飽和まで分配 型の吸着曲線にしたがつたこと，さらに，その飽和染着 量（表 2 の飽和溶解度と分配保数から計算できる）が容 媒の種類に関係なく，注ば同一の值を示したことなどか ら，この溶媒による被染物の凝集構造の弛解などが原因 と見られる染着有效体穦の变化は僅少と考々られる。

これゆ立，この塞験では，染着有効体䅡の值を同一と 仮定した。

したがつて，(2)式にしたがい，みかけの染着有效体 積(V)を定めた。

$V=\mathrm{PET}$ 物質の重量/PET 物質の比重

PET 物質の比重 $=1.38$

これにもとつき，染料濃度を計算し，（1）式を用いて 標準親和力の值を求めた。

このよ5にして求めた， $100^{\circ} \mathrm{C}$ の染料の標準親和力と 溶解度との関俰を, 四2に示した。

図 2 の関係については，Bird7) らが水溶液からアセテ 一ト瀻維を染色したときに，同様の直線関係が成立する ことを恝めている。著者らは，さらに溶媒の種類に関保 なくこの関係が成立することを認めた。他方，Giles ${ }^{8)}$ は上述の $\mathrm{Bird}^{7}$ 万の值を引用して染浴比打りる溶解度 と飽和染着量との間に密接な関係があることを強調して いる。これに関して，須田" は飽和染着量として用いた 值をエネルギ一的に考えれば，いずれの場合にも染料間 の差が小さく，その有意性は認め難いことを指摘した。 
著者方分配釈数 $\times$ 飽和溶解度から求めた飽和染着量 の値が染料の種類によつてあまり変わらず，また，溶媒 が買なつても飽和染着量の值が活とえど变からないこ と，才なわち，溶解度が大きく変わつてわ飽和染着量の 值が变わらないことなど考劣合わせると，Giles ${ }^{8)}$ が指 摘したように飽和染着量と溶解度との間に密接な関绿が あると考之るよりは，親和力と溶解度との間に密接な関 係があると考学るはらが妥当と思われる。

\section{4 溶解度と染料構造との関係}

前記の結果から，染浴の溶媒の種類に関係なく，溶解 度の値が小さいもの活ど分配係数が大さいことを知っ た。

これゆ党，染料の染色性を知るには，この溶解度の值 と染料㨞造との関係を明らかにすればよい。染料搆造の 評価としてはいろいろな方法があるが，藤田による無機 性/有機牲の值 ${ }^{10}$ を用いた。この值と溶解度との関係を， 無極性溶媒であるオクタンと極性溶媒である水儿ついて 求めた。この結果を図 3 に示した。

無極性溶媒，すなわち，有機性の值が極めて大きい才 クタンに対しては，有機性の做が大きい染料致ど溶解度 の值は大きく、したがつて, 吸尽は悪くなる。逆汇，極 性溶媒，すなわち，無機性の極めて大きい水に出いて は，無機性の值の大きい染料仼ど溶解度の值は大きくな る。このように同一染料でる染浴の溶媒の種類により, 染料の吸尽率は非常に異なる值を示した。しかし，館和 染着量（溶解度 $\times$ 分配係数の値）は溶媒の種類に閣係な く、ほ活一定の值を示した。な技，アントラキノンのカ

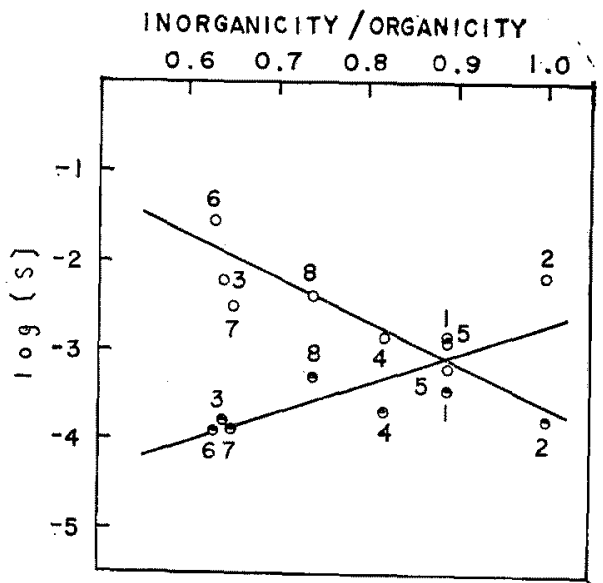

Fig. 3. Relationship between the solubility and inorganicity/organicity of dyes.

The numbers on the figure are the dye number of Table 1.

$\bigcirc$ : octane, $\ominus$ : water.
ルボニル基に対し， $\alpha$ 位の水酸基牯よびアミ，基が分子

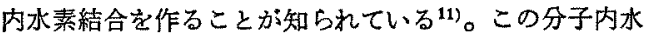
素結合による効果は，この無機性/有機性の值換算さ れていない。このことから考亲れば，直線から大きく外 れた染料番奇 2 拉よび，わずかに外れた染料番号 1 が直 線に，一周に近づくことが予想できる。

以上，PET 物質を無極性溶媒および極性溶媒から染 色した結果，その染色性は溶媒の種類に関係なく水溶液 の場合と同稼，分配型の吸着を示したこと，および、親 和力と溶解度の值の閫に直線的関係があつたことは，從 来この分散染料の染色過程が現象的に溶解として考觉ら れていたことを再確認するとともに，PET 物質一染料間 の結合の箽類がなんであるかは別として，染色は溶媒一 染料間および PET 物望一染料間の結合の強さのバラン スによつて支配されると考えられる。したがつて，PET 物質一染料間の結合の強さが大きく変わらない染料では， 溶婪々の親和力が大きい染料ほど吸尽が悪くなる。た えば，溶媒と分散力によつて結合しやすい染料任ど無極 性溶媒との親和力が強く，この溶媒から染色した場合吸 尽が覀くなる。逆に，水溶液中では，水分子との結合が 強い染料注ど吸尽が雳くなる。

3.5 分散染料の蒸気相と染着状態との間のエンタル ピー差 $\left(\Delta \boldsymbol{H}_{\mathrm{abs}}\right)$

分散染料の蒸気王と染着状態との間のエンタルピー差

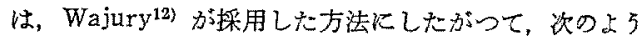
に決めた。

まず，表 2 に示した溶解度および分配係数のそれぞれ の温度変化から溶解熱と染色熱を求めた。この結果は表 3に示した。これらの值と，前報 ${ }^{16)}$ で求めた㫒華熱之の 值から(3)式にしたがい $\Delta H_{\mathrm{abs}}$ の値計算した。

これらの值を表 4 亿示した。

$$
A H_{\mathrm{abs}}=\text { 昇華熱一(溶解熱十染色熱) }
$$

Frank ら ${ }^{19)}$ は，吸着過程におけるニンタルピーの值 を，5部門に分割して教察している。この考えにしたが 完ば，溶解熱は次の過程が奇与していると考えられる。

(1) 染料分子一染料分子間の切断

（2）溶媒分子-溶媒分子間の切断

（3）染料分子-溶媒分子間の結合

また，染色蓺は次のbが笴与していると思われる。

(1) 染料分子-溶媒分子間の切断

(2) PET 分子一溶媒分子關の切断

(3) PET 分子一染料分子間の結合

(4) 溶煤分子同志の再結合

（5）PET 分子と染料分子とが結合した系に括ける 溶媒分子の再結合

以上の過程をもとに, 溶解熱と染色熱との和の值につ 
Table 3. Heat of solution and heat of dyeing from each of the solvents

\begin{tabular}{c|c|c|c|c|c|c}
\hline \multirow{2}{*}{$\begin{array}{l}\text { Dye } \\
\text { No. }\end{array}$} & \multicolumn{2}{|c|}{ Heat of solution (Kcal/mol) } & \multicolumn{3}{|c}{ Heat of dyeing (Kcal/mol) } \\
\cline { 2 - 7 } & octane & $\begin{array}{l}\text { n-buthyl } \\
\text { alcohol }\end{array}$ & water & octane & $\begin{array}{c}\text { n-buthyl } \\
\text { alcohol }\end{array}$ & water \\
\hline 1 & 10.4 & & 18.5 & -6.94 & & -12.0 \\
2 & 10.1 & 8.58 & 17.5 & -8.23 & -3.19 & -12.6 \\
3 & 9.85 & & 15.5 & -5.52 & & -11.3 \\
4 & 13.9 & & 10.4 & -3.34 & & -6.83 \\
5 & 13.6 & & 15.9 & -11.4 & & -11.6 \\
6 & 10.7 & & 9.51 & -4.85 & & -7.97 \\
7 & 11.8 & 9.52 & 15.0 & -7.17 & -4.33 & -11.0 \\
8 & 11.8 & & 11.6 & -8.35 & & -11.3 \\
\hline
\end{tabular}

一の値と打互に補償しあう結果とな る。溶解過程们抢ける染料一溶媒分 子間の結合と染色過程に扣ける染料 一溶媒分子間の切断とにともならて れぞれのエンタルピーの値は，兑れ らの過程に执いて，招互以補償し合 つていると考充られる。次法，染 色過程に和惊 PET 分子一溶媒分 子間の切断と PET 分子之染料分子 とが結合した系に颃ける溶媒分子の 再結合の過程にともならェンタルピ 一の值について教交てみる。PET分 子と溶媒分子間の切断にともなうエ

Table 4. Enthalpy changes ( $\Delta \mathrm{Habs}$ ) from dyed states to vapour states. (PET)

\begin{tabular}{l|c|c|c}
\hline \multirow{2}{*}{$\begin{array}{l}\text { Dyel } \\
\text { No. }\end{array}$} & \multicolumn{3}{|c}{$\Delta H_{\text {abs }}(\mathrm{Kcal} / \mathrm{mol})$} \\
\cline { 2 - 3 } & octane & $n$-buthyl alcohol & water \\
\hline 1 & 26.0 & & 23.0 \\
2 & 26.8 & 23.3 & 23.8 \\
3 & 27.0 & & 27.1 \\
4 & 22.7 & & 29.7 \\
5 & 34.6 & & 32.5 \\
6 & 25.7 & & 30.0 \\
7 & 27.5 & 27.3 & 28.1 \\
8 & 29.2 & & 32.4 \\
\hline
\end{tabular}

Table 5. Enthalpy changes $\left(A H_{\mathrm{abs}}\right)$ from dyed states to vapour states. (Acetate)

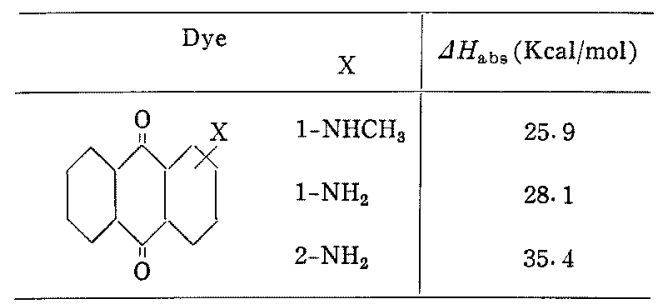

いて，次の上5に考えた。

溶解過程における溶媒分子閏の切断々染色過程に掠け る溶媒分子同志の再結合とにとむならエンタルピーの值 については，次のよ5に考えられる。染色過程に机い て，溶解していた染料が PET 分子との結合のために， 溶媒和していた溶媒分子を放出する。この放出された溶 分子の数は，溶解過程における溶媒分子間の結合が切ら れた溶媒分子の数と等しく，したがつて，これらの溶媒 分子の再結合の過程にともなろェンタルピーの值は, 溶 解過程における溶媒分子間の切断にともならエンタルピ
ンタルピーの値は，同一の溶媒を用いた場合，同一の值 を示す。PET 分子と染料分子とが結合した系における 溶媒分子の再結合は，同一の溶媒を用いた場合，その過 程に和けるエンタルピーの值は，染料の構造が著しく変 わらないかぎり，はとえど变わらいことが考克られる。 そして，この值は PET 分子之溶婪分子間の切断とにと むならェンタルピーの値とかなりの割合に格いて補償し めつていることが推湘される。したがつて, 以上の過程 に㧍けるニンタルピーの值の総和は，かなり小さく，同 一溶媒を用いた場合，その染料構造が著しく変わらない かぎり，一定の值を示すことが考えられる。しかしなが ら，異なる溶媒を用いた場合，この值は異なる檤を示す と思われる。これけえ，同一溶媒学使用した場合には， 溶解熱之染色熱の和の值惊，染料分子一染料分子間の切 断と PET 分子一染料分子間の結合とに寄与するェンタ ルピー差の値ブラス $\alpha$ (定数) となる。さらに, 昇苹熱 が格子エネルギーに等しいとして取扱われていること ${ }^{14}$ など考え合わせれば，(3)式の $\Delta H_{\mathrm{abs}}$ の值は，染料一 PET 物質間の結合エネルギーの值プラス $\alpha$ (定数) と考 えてる上い。したがつて, 同一溶媒について求めた $\Delta H_{\mathrm{abs}}$ の值を用いて, PET-染料分子間の結合の強さの大小関 係を議諭することがでさる。これ功光， $\Delta H_{\mathrm{abs}}$ の值さ用 いて PET 物質に対する染着機構を議鈜した。

$3 \cdot 5 \cdot 1$ アントラキノン系

まず,モノアミノ系について議諭する。

須田 ${ }^{2)}$ は，エチルアルコール溶液からアせテート究染 色した場合の結晶状態のェンタルピー基準が大体等しい として、モノアミノアントラキノンについて染着機榡る

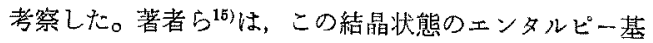
準、寸なわち，昇華熱を测定したので，これらの值と， 須田の染着状態と結晶状態のエンタルピー差とから（3） 式にしたがい $\Delta H_{\mathrm{abs}}$ の值を計算した。その結果を表 5 にした。な拉、1ーメチルアミノアントラキノンの界華熱 
の值は Bradley ${ }^{16)}$ の值を採用した。

Vicckerstaff らによつて，考えられた水素結合機構す なわり（4)式からの立場で素 5 に示した染料をみる。 一般伿

$$
\underset{-\mathrm{O}}{\mathrm{CH}_{3}}>\mathrm{C}=\mathrm{O} \cdots \mathrm{H}-\mathrm{N}-\mathrm{Dye}
$$

アントラキノンの $\alpha$ 位のアミノ基は分子内水素結合を作

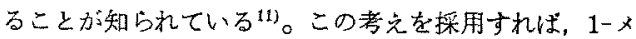
チルアミノ，1ーアミノ枯よび 2-アミノ置撸体は，水菜 結合能力のある遊離水素原子を，それそれれ，0，1およ び 2 個，持つことになる。すなわわ，この順序にしたが い $\Delta H_{\mathrm{abs}}$ の値も增加している。

これら，モノアミノ瞋換体に共通した染料一アセテー 卜緎維間の結合，すなわら，分散力，双極子一双極子間 相互作用，束た，Giles ${ }^{18)}$ によて指摘され，須田 ${ }^{9)}$ よつて明らかにされた $\alpha-\mathrm{CH} \cdots \mathrm{X}$-Dye 型水素結合など の結合エネルギーは，これらの供試染料の場合，すべて において，ほぼ同じであると思かれる。したがつて，す し、これらの分子間力について，結合エネルギーの加成 性方䛨されるならば，1ーアミ，直換体の1個の水素結合 エホルギーの值は，1-アミノ置换体の $\Delta H_{\mathrm{a} \text { bs }}$ の值から 1ーメチルアミノ置換体の $\Delta H_{\mathrm{abs}}$ の值を差引き，さらに この值から，直鎖の $\mathrm{CH}_{2} 1$ 個当りの分散力 $(1.0 \mathrm{Kcal} /$ $\mathrm{mol})^{19)}$ 考差引いた值になる。すなわり，約 $3 \mathrm{Kcal} / \mathrm{mol}$ に相当する。同様の方法にしたがい，2-2 $\mathrm{NH}_{2}$ 置換体の 1 個当りの水素結合エネルキーは，約 $5 \mathrm{Kcal} / \mathrm{mol}$ とな る。これらの値は, 結晶状態にある化合物の N-H…0 型 水素結合エネルギー $(3 \sim 7 \mathrm{Kcal} / \mathrm{mol})$ の值 ${ }^{20)}$ とよく一 致している。したがつて，アントラキノン核についたア ミノ基の遊離の水素原子はアセテートのカルボニル基の 酸索原子と水素結合を作万能力があると考えるべであ 古。

1：4ージアミノ，招よび，1-アミノー4-オキシ置掺体と PET 物質との結合エネルギーについて議諭する。

前述のそノアミノ置換体について，アミノ基の遊離水 素原子がカルボニル基の酸菜原子と水素結合を作ること 艾知つた。この考光にしたが党ば、1:4ージアミノ一，特 よび，1ーアミノー4ーオキシ頨換体の PETーカルボ二ル基 に対する水素結合能力は，それぞれ，2就よ゙1個でむ

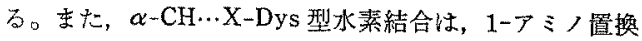
体の場合とほとんど变わらないと思われる。双極子一双 極子間間相互作用は，1-アミノ置換体 $(1.5 \mathrm{D})^{21)}$ より む， $1: 4$-ジアミノ置換体执よび 1-アミノー4ーオキシ置

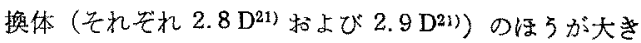
い。また，アントラキノン核とPET 分子關の分散力は, これらの化合物のすべてにおいて等しいことが考えられ
る。

以上のことから考えれば，1：4ージアミノ置換体の

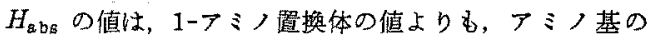
遊離水素原子に上る水素結合㧍よび双極子モーメントの 増加に上る双極子一双極子間相互作用だけ分子間力か， 增加することになる。また，1ーアミノー4ーオキシ置換体 の $\Delta H_{\mathrm{abs}}$ は，その双極子モーメントが 1-アミノ喵換 体より大きいのでこれにもとつく分子間力だけ，1-ア ミ，置換体上りも，增加することになる。しかし，実際 には，これら $\Delta H_{\mathrm{abs}}$ の値は表 4 にみられるよ5に，才 クタンからの場合は，ほぼ等しい值（しかし，わずかで はるるが、1ーアミ，置換体が最大の值を示した）であ り，水溶液からの場合，最す小さい結合エネルギーを示

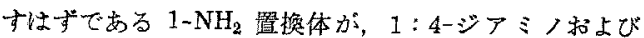
1-アミノー4-オキシ置撸体に比へ，数 $\mathrm{Kcal}$ 大きい值を 示した。この矛盾に対する説明は明らかでない。

$3 \cdot 5 \cdot 2 \quad 2: 4$-ジフェニルアミン系染料

2:4-ジニトロジフェニルアミンと PET 物筫の結合

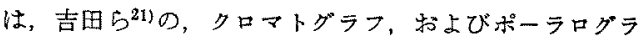
フの研究から明らかにされたように，染料の二トロ基と PET 物質のエステル基との間隹，双極子-双極子間相互 作用が生じていることが栲えられる。また，須田 ${ }^{9)}$ の考 えにしたがえば，PET 物質の $\alpha \cdot \mathrm{CH}$ と染料一（メは プロトン受容体）との間に水素結合希作ることも考えら れる。水溶液からの $2: 4$-ジニトロフェニルアミンの $A$ $H_{\mathrm{abs}}$ の檤は，この染料の界華熱 $(31.5 \mathrm{Kcal} / \mathrm{mol})$ と注 注等しい值を示した。このことについて，Majury ${ }^{12}$ は 染料一染料間の結合か PET 物質一染料間の結合と類似 なるのであることを推論している。

この場合当，当然，Majury ${ }^{12)}$ の説のよ5に考えられ るが，もし，定性的な教察が許されるならは，次のよ5 に考点られる。PET-染料間の結合は，染料一染料間の結 合にはなかつた $\alpha$-CH $\cdots \mathrm{X}$-Dye 型水素結合が存在する ことが教えられる。他方，PET-染料間の分散力は立体 障害のため，染料一染料間の場合よりも小さくなる傾向 加るる。た，阙㥞に，双極子一双極子間相互作用的梁 料之 PET の双極子モーメントから考克れば小さくなる

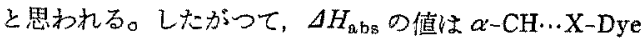
型水素結合による増加と分散力拉よび双極子一双極子閒 相互作用の低下とが互に補償し合い，昇華熱に近い値を 示したと思われる。

4’ーオキシー，および 4'ーアミノー，2:4ージニトロジフ エニルアミンは帠華熱の测定の結果 ${ }^{15)}, 4^{\prime}$ の位置のオキ シ基战よびア、基の水素原子がプロトン供与体となつ て，水素結合を作ることを明らかにした。PET物質一 染料間の場合も，同様に，PET 物質のカルボニル基と 
水素結合を作ることが考えられる。1-オキシ監換体の

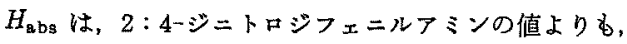
乐溶液の場合， $2.5 \mathrm{Kcal} / \mathrm{mol}$ 大きな值を示した。るし， 加成性が仮定されるならば，この増加した値は，4'オキ シ基の水素原子にもとつくく，水素結合エネルギーの傎に 相当する。この值は，昇華熱から求めた水素結合政ル

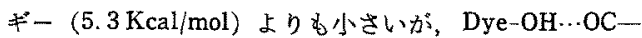
PET 型水素結合が起こつていることが明らかになつた。 $4^{\prime}$ ーアミノ置換体の $\Delta H_{\mathrm{aba}}$ は, $2: 4$-ジニトロジフェニ ルアミンとほぼ等しい值を示した。このことは，4'ー ミノ置換体と $2: 4$-ジニトロジフェニルアミンの昇華熱 の差 ${ }^{15) か ゙ ~} 1.8 \mathrm{Kcal} / \mathrm{mol}$ でありこのアミノ基にもとつ く，水菜結合は弱いことを示している。したがつて，染 料-PET 物質間においても，このアミノ基にもとつく水 素結合溺いことが考劣られる。そのためか，アミノ置 換体の場合，アミノ基にもとつく分子間結合エネルギー の增加は、ほとんど示さなからた。

$3 \cdot 5 \cdot 3$ アソ゚ベンゼン系染料

清水らは ${ }^{23)}$ ，一連のアゾペンゼン系分散染料につい て，㫧華熱と，PET 物質に対する気相か５0染色熱学 むとめ，PET 物質と，アゾベンゼン系分散染料との結 合について論じている。著者らは，2 個のアジベンゼン 系分散染料しか，研究してないので，清水ら ${ }^{23)}$ のPET 物質に対するアゾベンゼン系分散染料の結合説をうわ变 わるものは得られなかつた。

\section{$3 \cdot 5 \cdot 4$ 分散力について}

染料一染料間の結合エネルギーに関しては，結合エネ ルギーの加成性の仮定がかなり满足に成立していた。こ のことは，立体障害による影響がかなり少ないことが考 之られる。他方，多くの昜合，分散染料の昇華熱の值と PET 物質と染料分子間の結合エネルギー $\left(\Delta H_{\mathrm{a}, \mathrm{bs}}\right)$ の值 が大きく違わなかつた。これについて，Majury ${ }^{12)}$ は, 染料一染料間の結合と染料一絨維間の結合が類似なるの であることを述べている。これらのことから，PET 物 啠と染料との結合に和いても，かなりに，結合エネルギ 一の加成性が存在すると思われる。したがって，むし， このように結合ニネルギーの加成性が諗められると仮定 すれば，分散力は次の上うに考えられる。

Giles $^{18)}$ によつて指摘されたように, PET物質のペン ゼン核が染料のアントラキノン核和よびジフェニルアミ ンをたは，アゾベンゼンのベンゼン核と分散力によつ て結合することが考えられる。この值は，芳香族炭化水 素の炭素 1 個当りの結晶格子土ネルギーが $1.75 \mathrm{Kcal} /$ mol であることが知られているので，このベンゼン核だ 汀に生じる分散力は $10.5 \mathrm{Kcal} / \mathrm{mol}$ にもなり，これは， アントラキノン染料の場合, PET-染料間の結合エネル
ギーの約 $40 \%$ にも当る。さた：ジフェニルアミン，特 よびアゾベンゼンの場合は, 約 $35 \%$ K当る。もし，ジ フェニルアミンとアゾペンゼンの場合，2 個のベンゼン 核が寄与しているとすれば，全体の結合エネルギーの $70 \%$ にる相当することになる。このよ5なことより考 えれば，PET 物質一分散染料間の結合は，かなりベン ゼン核によつて，支配され，そのもので，双極子一双極 子間相互作用および氷菜結合が起こつていると解积でき る。

\section{4. 結論}

染浴の溶媒が変わつたときに分散染料の染色性と染着 機構がどのよに変わるかを知るために，オクタン，nブチルアルコールおよび承溶液中に打汀る分散染料の飽 和溶解度怙よびこれらの溶媒から染色したときの分配俰

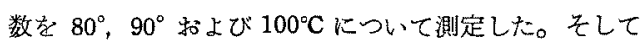
染料の漞和力，溶解熱および染色熱学尊いた。これらの

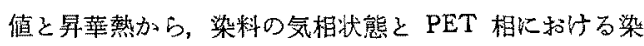
着状態の標準エンタルピーの差 $\left(\Delta H_{\mathrm{abs}}\right)$ を導いた。そ して、つぎの結合を見い出した。1. 溶媒の種類に関保 なく，溶解度が大きくなるはど親和力の值は小さくなつ た。2. 染料の無機性/有機性の値が大きくなるぼ水 溶液における染料の溶解度は大きくなつた。しかし， オ クタンの場合は小さくなつた。 3 . 供試分散染料の $A$ $H_{\text {abs }}$ の值 $(23 \sim 35 \mathrm{Kca} / \mathrm{mol})$ 力 5 , 分散染料々 $\mathrm{PET}$ 物 質間の結合には，ペンゼン核にるとつく分散力がかなり 大きく寄与し，この他に，双極子一双極子間相互作用和 よび水素結合などが寄与していると考えられる。

本研究を行な5にあたり有益な示睃と討論を賜つた東 京工策大学飯島俊郎助教授に深く感謝いたします。な打 研究費の一部は昭和 41 年度東海学術奖励会研究助成金 によつた。付記して感謝を表します。

\section{文献}

1) H.J. White; Textile Res. J., 29, 6 (1959) 30 , 329 (1960)

2) 須田昌男；䋐学誌，19,136,143（1963）

3) 関戸 実, 小島 弘; 緎学誌, 21，644 (1965)

4）日本化学会編；化学便㹂，丸善 (1958) p. 416

5) 例光ば, M. J. Schuler, W. R. Rewington；Disc. Faraday Soc, 16, 201 (1953)

6) 金丸㖕；化学々工業，12，89（1959）

7) C.L.Bird, P.Harris ; J.Soc. Dyers Colourists, 73, 199 (1957)

8) C.H.Giles; Textile Res. J., 31, 141 (1961)

9）須田昌男；緎学誌，21，223（1965）

10）藤田 穆；化学の領域, 11, 719（1957）

11）例立ば M.S.C. Flett；J.Chem. Soc., 1444 (1948)

12) T. G. Majury ; J.Soc. Dyers Col., 70, 442(1954) 
13) P. Molyneux and H.P. Frank; J. Am. Chem. Soc, 83, 3169 (1961)

14) R. S. Bradley 5; J. Chem. Soc., 1953, 1681, $1684,1688,1690$

15）鶴岡信三，小島 弘; 絩学誌，24，27 (1968)

16) R.S. Bradley, C. L. Bird, F. Jones; Trans. Faraday Soc., 56, 23 (1960)

17) T. Vickerstaff; The Physical Chemistry of Dyeing, 2 nd ed., Oliver and Boyd, Chap., (1954)
18) C.H.Giles; Textile. Res. J., 31, 141 (1961)

19）大本道勋他䣓；構造有機化学, p. 160 (1965) 東 京化学同人

20）笑 集三，千原秀昭，鈴木啓介; 岩波講座，現代 化学, 水萦結合, p. 41 (岩波望店)

21) B. Kramer; Reyon Zellwoole, (1955) 607, 682

22）吉田善一, 田尻弘水, 小田良平; 工化䛪, 65, 1064,1067 (1962)

23）清水，融，片山恒襀，小島正雄；学振，120委員 会年次報告, Vol. 17, 60 (1965) 